\title{
The Influence of Social Support to the Quality of Life of Tuberculosis Patients in Depok, West Java Province, Indonesia
}

\author{
Siti Nur Anisah ${ }^{1}$, Ratna Djuwita $^{2} \&$ Mondastri K. Sudaryo ${ }^{2}$ \\ ${ }^{1}$ Agency of the Empowerment and Development of Human Resources in Health, Ministry of Health, Indonesia \\ ${ }^{2}$ Department of Epidemiology, Faculty of Public Health, Indonesia University, Depok, West Java, Indonesia \\ Correspondence: Ratna Djuwita, Faculty of Public Health, Indonesia University, Depok, West Java, Indonesia, J1 \\ Lingkar Kampus Raya Universitas Indonesia, Kota Depok, Provinsi Jawa Barat 16424, Indonesia. E-mail: \\ djuwita257@gmail.com
}

Received: September 6, 2020 Accepted: October 1, 2020 Online Published: October 23, 2020

doi:10.5539/gjhs.v12n12p112 URL: https://doi.org/10.5539/gjhs.v12n12p112

\begin{abstract}
The quality of life of Tuberculosis (TB) patients is very important to be considered due to infectious disease is chronic that it can affect quality of life. In order to improve quality of life is by providing social support to TB patients. This study aims to discuss the influence of social support to the quality of life of TB patients. This was a longitudinal study (repeated measurements). Data collection with interviews to respondents using the WHOQOL-BREF and Multidimensional Scale of Perceived Social Support (MSPSS). Data analysis using General Estimation of Equotion. The results showed that social support has a strong influence to the quality of life of TB patients $(\mathrm{OR}=7.9)$; An influential source of social support to improve the quality of life of TB patients were family, friends and significant others. Family support provides the highest contribution with an OR of 19.7; An influential type of social support to improve the quality of life of TB patients were emotional, informational and companionship support. Emotional support provides the highest contribution with an OR of 7.4. Social support to TB patients given at the $5^{\text {th }}$ month of treatment have a positive impact on the quality of life with PAR $\%$ was $70 \%$. This study recommends improving the social support to TB patients to increase quality of life of TB patients.
\end{abstract}

Keywords: Quality of life, WHOQOL-BREF, Social Support, MSPSS, Tuberculosis

\section{Introduction}

\subsection{Introduce the Problem}

Quality of life is the concept of multidimensional which is more extensive than simply measuring morbidity and mortality (Payot \& Barrington, 2011). In 1995, the WHO recognized the importance of evaluating and improving people's quality of life. WHO states that measuring health outcomes, not only based on saving lives, but also in terms of improving quality of life (The WHOQOL Group, 2005).

Tuberculosis (TB) is one of the infectious disease as the highest contributor to the disease burden in Indonesia (MOH Indonesia, 2016). Tuberculosis can affect the patients' quality of life such as psychological, physical, social functioning (Dhuria, Sharma, \& Ingle, 2008). Putri, Wahiduddin, and Arsyad research on Pulmonary Tuberculosis patients at BBKPM Makassar with cross sectional study design and using WHOQOL-BREF questionnaire reported that out of 90 research samples, there were $55.6 \%$ (50 people) who had poor quality of life (Putri et al., 2013). One of the ways that can be done to improve the quality of life is by giving social support to TB patients from the health worker, communities or families of patients who have contributed substantially in improving the treatment of TB patients with the supervision and cheering the patients against the disease (Nita Yunianti Ratnasari, 2012).

The study of the influence of social support to quality of life needs to be considered some factors that have a large impact on social support and quality of life, namely the age of TB patients. The age categorization of TB patients is based on a cut-off of 15 years, specifies by pediatric TB patients (age $<15$ years) and adult TB patients (age $\geq 15$ years) (MOH Indonesia, 2016). The response of TB Patients to support social and quality of life at the age of adulthood will be more easily obtained than pediatric TB patients because children have a dependency on the parent (Kusmiyati, 2016). For that this study was conducted, the study of the influence of the social support of the quality of life is carried out on the subject of the homogeneous that patients with TB adults aged $\geq 15$ years. 


\subsection{Aim of The Study}

The study aimed to determine the effect of social support on the quality of life of TB patients in the prospective cohort with repeated measurements.

\section{Method}

\subsection{Participant (Subject) Characteristics}

Subjects of this study were 209 patients who newly diagnosed that confirmed by sputum smear microscopic as Pulmonary Tuberculosis at the health centers of Depok City, West Java Province, Indonesia, aged $\geq 15$ years old and domiciled in Depok City, West Java Province, Indonesia, which had complete medical records and was willing to be a research respondent by signing an inform consent. The exclusion criteria were pediatric and extra pulmonary TB patients.

\subsection{Sampling Procedures}

\subsubsection{Sample Size}

The sample size is calculated to see the difference in proportion of the two groups in the longitudinal study design with more than 1 (one) follow up or repeated measurement, then using a large sample formula from Twisk (Twisk, 2013). A number of samples assuming that this study had a $95 \%$ confidence level with $\alpha$ of $5 \%$. Based on the above calculation results obtained $\mathrm{N}=100,402$ rounded up to 100 tuberculosis patients in unsupportive social support groups, and 100 tuberculosis patients in supportive social support groups. Consider to loss to follow up during the observation period, the number of samples in this study will be increased by $10 \%$ (10 people) for each group, so tuberculosis patients in the social support group are not supportive of 110 people, and 110 tuberculosis patients in the supportive social support group.

\subsubsection{Measures and Covariates}

The study was carried out using an observational design with a prospective cohort (longitudinal study). Repeated measurements (baseline, $2^{\text {nd }}$ month, $5^{\text {th }}$ month, $6^{\text {th }}$ month) conducted was to assess data were gathered in all (35) health centers in Depok City with the time of the study was August 2017 - September 2018. The Indonesian version of the WHOQOL-BREF (4 domains: physical health, psychological, social relation and environmental) was created as an instrument to measure QOL of Tuberculosis patients (the Cronbach's Alpha coefficient of total QOL was 0,880). Although the WHOQOL-BREF has been used in 23 other countries (Alexander et al., 2005), the use of WHOQOL-BREF for Tuberculosis patients is still not widely practiced, especially in Indonesia. Moreover, the Indonesian version of Multidimensional Scale of Perceived Social Support (MSPSS) modified with Tuberculosis (the Cronbach's Alpha coefficient of total Social Support was 0,950) has been used as an instrument to measure social support received by the TB patients. Social support consists of source social support (support from family, friends, doctor and significant others) (Zimet, Dahlem, Zimet, \& Farley, 1988) and type of social support (emotional, informational, tangible and companionship support). Emotional support is the offering of empathy, concern, affection, love, trust, acceptance, intimacy, encouragement, or caring. Informational support means the provision of advice, guidance, suggestions, or useful information related TB to someone. Tangible support is the provision of financial assistance, material goods, or services. Companionship support is the type of support that gives someone a sense of social belonging. This can be seen as the presence of companions to engage in shared social activities (Wikipedia The Free Encyclopedia, n.d.). The determination of 'bad' or 'good' category of quality of life uses the 60 percentiles (50.67). With the categorization is based on the cut off of this. Moreover, the categorization of social support is non-supportive and supportive based on the parameters of the mean score (105.94).

\subsection{Research Design}

This was a longitudinal study (repeated measurements). Data collection with interviews to respondents using the WHOQOL-BREF questionnaire for quality of life data and Multidimensional Scale of Perceived Social Support for social support data. Data analysis using logistical regression analysis for repeated data measurement is General Estimation of Equotion. The impact of social support to the quality of life of TB patients is assessed by calculating Attributable Risk (AR), Attributable Risk Percent (AR\%), Population Attributable Risk (PAR) and Population Attributable Risk Percent (PAR\%).

\section{Results}

\subsection{Participant Characteristics}

From 209 patients who diagnosed as newly patients by sputum smear microscopic as Pulmonary Tuberculosis at 
the health centers of Depok City, West Java Province, there were age of 25-34 years (27.8\%), male (60.3\%), high school education $(47.8 \%)$, working $(60.3 \%)$, married $(67.9 \%)$, have medical insurance $(64.1 \%)$, no have HIV (99.2\%) and no have DM (82.3\%).

\subsection{Quality of Life of TB Patients and Social Support to TB Patients}

Two information namely quality of life of TB patients and social support to TB patients are describes in Table 1 .

Table 1. Quality of Life of Tuberculosis Patients and Social Support to Tuberculosis Patients at Specific Follow Up (Baseline, $2^{\text {nd }}$ month, $5^{\text {th }}$ month, $6^{\text {th }}$ month $)(\mathrm{n}=209)$

\begin{tabular}{lllllllllll}
\hline & \multicolumn{2}{l}{ Baseline } & \multicolumn{2}{c}{$\mathbf{2}^{\text {nd }}$ month } & \multicolumn{2}{c}{$\mathbf{5}^{\text {th }}$ month } & \multicolumn{2}{c}{$\mathbf{6}^{\text {th }}$ month } & p value \\
\cline { 2 - 9 } & $\mathbf{n}$ & $\mathbf{\%}$ & $\mathbf{n}$ & $\mathbf{\%}$ & $\mathbf{n}$ & $\mathbf{\%}$ & $\mathbf{n}$ & $\mathbf{\%}$ & \\
\hline Quality of life & & & & & & & & & \\
Bad & 206 & 98,6 & 172 & 82.3 & 83 & 39,7 & 41 & 19,6 & 0,000 \\
Good & 3 & 1,4 & 37 & 17,7 & 126 & 60,3 & 168 & 80,4 & \\
\hline Social Support & & & & & & & & & \\
Non-supportive & 113 & 54,1 & 105 & 50,2 & 89 & 42,6 & 61 & 29,2 & 0,000 \\
Supportive & 96 & 45,9 & 104 & 49,8 & 120 & 57,4 & 148 & 70,8 & \\
\hline
\end{tabular}

Significant level: $5 \%$.

The quality of life of TB patients is good at baseline were $3(1.4 \%)$ then rise in the follow up in sixth month into $168(80.4 \%)$, whereas Quality of life of TB patients with is bad at baseline were $206(98.6 \%)$ and then decreased to $41(19.9 \%)$ at $6^{\text {th }}$ month. The relationships were significant $(\mathrm{p}$-value $=0.000)$ between the quality of life with the time of measurement. The more the length of treatment, the good quality of life of TB patients is getting higher and the bad quality of life of TB Patients is getting low. The description of support social to the TB patients is known that at baseline, supportive social support to the TB patients is found low were $96(45.9 \%)$ subsequently at follow up in $6^{\text {th }}$ month rise into $148(70.8 \%)$, and non-supportive social support the highest found at baseline namely 113 $(54.1 \%)$ and then decreased at $6^{\text {th }}$ month becomes $61(29.2 \%)$. There is a significant relationship ( $p$-value $\left.=0.000\right)$ between the social support with the measurement of time. The length of treatment, the supportive social support to the TB patients is getting higher and non-supportive social support to the TB patients is getting lower.

\subsection{Social Support to the TB Patients}

Social support to the TB patients can be distinguished based on sources of social support and type of social support. An overview of the sources and type of social support to the TB patients is presented in Figures 1 and 2.

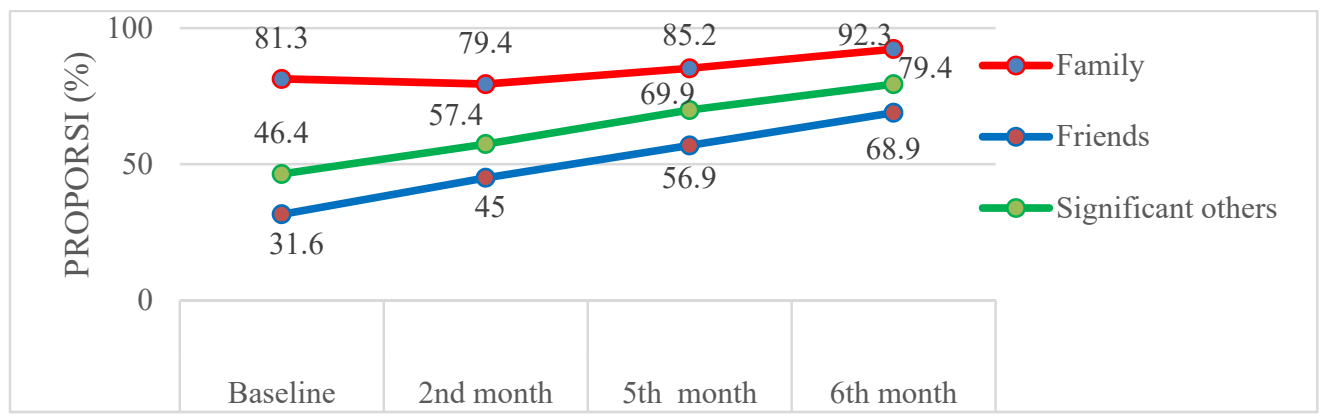

Figure 1. Distribution of Proportion (\%) Sources of Supportive Social Support to Tuberculosis Patients

Description of sources of social support that comes from family, friends and significant others can be identified that at baseline supportive social support over many obtained from family, namely by $170(81.3 \%)$ and at $6^{\text {th }}$ month increase to $92.3 \%$. The relationships were significant $(p$-value $=0.000)$ between the three sources of social support to the TB patients with a measurement of time. The longer period of treatment, supportive social support to the TB patients is getting higher and non-supportive social support to the TB patients is getting lower. 


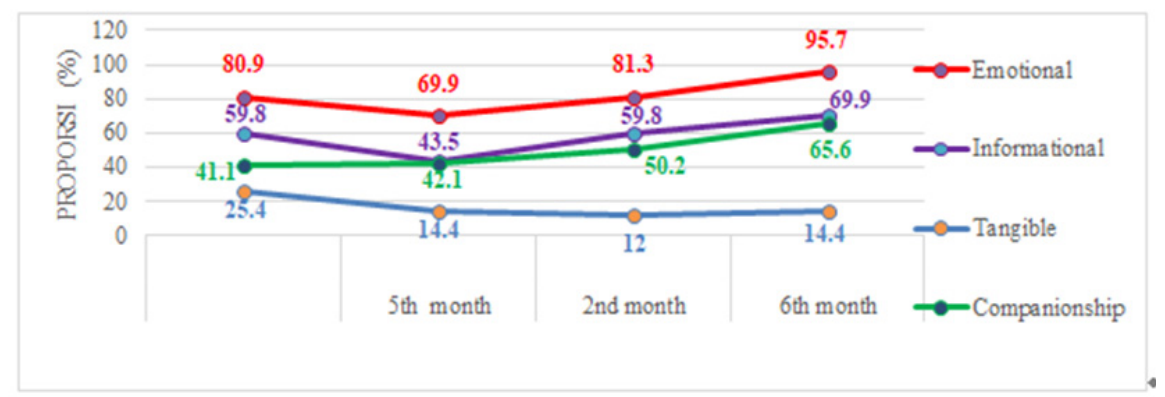

Figure 2. Distribution of Proportion (\%) Type of Supportive Social Support to Tuberculosis Patients

Figure 2 above shows that at baseline, the highest type of supportive social support was emotional was 169 $(80.9 \%)$, then $6^{\text {th }}$ month increasing to $95.7 \%$. while the lowest type of supportive social support is tangible by 53 (25.4\%) and decreasing in $6^{\text {th }}$ month becomes $14.4 \%$. There was a tendency the longer period of treatment, the type of supportive social support to the TB patient is getting higher, except for the tangible support the longer period of treatment, the tangible support is getting lower.

\subsection{The Influence of Social Support to Quality of Life of TB Patients}

Based on the result of multivariate analysis with the General Estimation of Equation (GEE), the final model of the influence of social support to the quality of life of TB patients is presented in table 2.

Table 2. Final Model of the Influence of Social Support to Quality of Life of Tuberculosis Patients after Controlled Covariates

\begin{tabular}{|c|c|c|c|c|c|c|}
\hline \multirow{2}{*}{ Variable } & \multirow{2}{*}{ B } & \multirow{2}{*}{ SE } & \multirow{2}{*}{ p-value } & \multirow{2}{*}{ OR } & \multicolumn{2}{|c|}{ 95\% CI OR } \\
\hline & & & & & Lower & Upper \\
\hline \multicolumn{7}{|l|}{ Sosial Support } \\
\hline Suportive & 2,071 & 0,177 & 0,000 & 7,9 & 5,6 & 11,2 \\
\hline Not Suportive & Reff & & & 1 & & \\
\hline \multicolumn{7}{|l|}{ HIV } \\
\hline Yes & $-1,527$ & 0,353 & 0,000 & 0,2 & 0,1 & 0,4 \\
\hline No & Reff & & & 1 & & \\
\hline \multicolumn{7}{|l|}{ DM } \\
\hline Yes & $-0,378$ & 0,189 & 0,046 & 0,7 & 0,5 & 0,5 \\
\hline No & Reff & & & 1 & & \\
\hline
\end{tabular}

Significant level: $5 \%$.

The results of the analysis showed that TB patients with supportive social support had a 7.9 times chance ( $95 \%$ CI: 5.6-11.2) to have a better quality of life than TB patients with non-supportive social support after controlling comorbid factors (HIV and DM).

In this study, measurements of social support to TB patients were carried out 4 times at baseline, $2^{\text {nd }}$ months, $5^{\text {th }}$ months and $6^{\text {th }}$ months. The effect of the time for providing social support to TB patients most needed to improve the quality of life of TB patients. Improvement in the quality of life of TB patients has increased from $2^{\text {nd }}$ month, $5^{\text {th }}$ month and 6th month. The information on the source and type of social support that influences to the quality of life is presented in Table 3 . 
Table 3. Analysis of General Estimation of Equation (GEE) The Influence of Source of Social Suport to Quality of Life of TB Patients

\begin{tabular}{|c|c|c|c|c|c|c|}
\hline \multirow{2}{*}{ Social Support } & \multirow{2}{*}{ B } & \multirow{2}{*}{ SE } & \multirow{2}{*}{ p-value } & \multirow{2}{*}{ OR } & \multicolumn{2}{|c|}{ 95\% CI OR } \\
\hline & & & & & Lower & Upper \\
\hline \multicolumn{7}{|c|}{ Source of Social Support } \\
\hline \multicolumn{7}{|l|}{ Family } \\
\hline Non-Suportive & Reff & & & 1 & & \\
\hline Suportive & 2,981 & 0,531 & 0,000 & 19,7 & 6,9 & 55,8 \\
\hline \multicolumn{7}{|l|}{ Friend } \\
\hline Non-Suportive & Reff & & & 1 & & \\
\hline Suportive & 0,992 & 0,199 & 0,000 & 2,7 & 1,8 & 4,0 \\
\hline \multicolumn{7}{|l|}{ Medical Dokter } \\
\hline Non-Suportive & Reff & & & 1 & & \\
\hline Suportive & $-0,719$ & 0,213 & 0,001 & 0,5 & 0,3 & 0,7 \\
\hline \multicolumn{7}{|c|}{ Significant Others } \\
\hline Non-Suportive & Reff & & & 1 & & \\
\hline Suportive & 0,961 & 0,210 & 0,000 & 2,6 & 1,7 & 3,9 \\
\hline \multicolumn{7}{|c|}{ Type of Social Support } \\
\hline \multicolumn{7}{|c|}{ Emotional Support } \\
\hline Non-Suportive & Reff & & & 1 & & \\
\hline Suportive & 1,995 & 0,433 & 0,000 & 7,4 & 3,2 & 17,2 \\
\hline \multicolumn{7}{|c|}{ Informational Support } \\
\hline Non-Suportive & Reff & & & 1 & & \\
\hline Suportive & 0,806 & 0,195 & 0,000 & 2,2 & 1,5 & 3,3 \\
\hline \multicolumn{7}{|c|}{ Tangible Support } \\
\hline Non-Suportive & Reff & & & 1 & & \\
\hline Suportive & $-0,781$ & 0,218 & 0,000 & 0,5 & 0,3 & 0,7 \\
\hline \multicolumn{7}{|c|}{ Companionship Support } \\
\hline Non-Suportive & Reff & & & 1 & & \\
\hline Suportive & 1,132 & 0,189 & 0,000 & 3,1 & 2,1 & 4,5 \\
\hline
\end{tabular}

An influential source of social support to improve the quality of life for TB patients was support from family, friends and significant others. Family support provides the highest contribution to improving the quality of life of TB patients with an OR of 19.7. The emotional, informational, tangible and companionship support has a statistically significant effect ( $\mathrm{p}$-value $=0,000$ ) to the quality of life of TB patients. The type of social support that affect improving to the quality of life of TB patients were emotional, informational, and companionship support. Emotional support provides the highest contribution to improve the quality of life of TB patients with an OR of 7.4.

The analysis results for the Attributable Risk Percent (AR\%), at baseline was 3\%, at the 2nd-month follow-up was $36 \%$, at the fifth-months follow up was $74 \%$, and at the sixth-month follow up was $86 \%$. The analysis result for Population Attributable Risk Percent (PAR\%) shows that at baseline was 2\%; at the 2-month was 23\%; at the 5th-month was $70 \%$, and at the 6th-month was $63 \%$.

\section{Discussion}

In this study, the number of male TB patients was more than female. These results are following previous studies conducted by Pasipanodya, Miller, Mauricio Vecino, Drewyer, and Weis (Pasipanodya et al., 2007) where the 
ratio of male and female tuberculosis patients was $69 \%$ : $31 \%$. WHO (WHO, 2010) also reports that every year there are $70 \%$ more TB sufferers in men than women. Based on age groups, most TB patients in this study were productive ages, namely age 25-34 years and 45-54 years. Previous research conducted by Tety and Turniani also found the most TB sufferers at the age of 16-45 years (R. Tety \& Turniani L, 2006). WHO states that the highest incidence of pulmonary tuberculosis is usually about the age of young adults between $15-44$ years, of which 75\% are of productive age (MOH Indonesia, 2016). Formal education of respondents in this study mostly half (47.8\%) of TB patients have a high school education. These results were consistent with research conducted by Adnan, Perwitasari, and Mulyani that TB patients are found at the high school level (45.9\%) (Adnan, Perwitasari, \& Mulyani, 2014). Research conducted by Tinartayu and Riyanto found that the majority (44.4\%) of pulmonary TB patients had a high school education (Tinartayu \& Riyanto, 2015). More TB patients in this study were married. This is the same as the results of research by Patel et al who found $74 \%$ of TB patients were married (Patel, Ramanuj, \& Bala, 2014). More TB patients in this study worked than those who did not. Previous research conducted by Hadifah, Amri Manik, Zulhaida, and Wilya found that $80 \%$ of Tuberculosis Patients worked (Patel et al., 2014). The incidence of TB in people who work may be caused by the high level of activity and mobility that provides greater opportunities for contact with others including TB patients, so the risk of contracting TB is greater (MOH Indonesia, 2016).

In terms of ownership of health insurance, in this study most (64.1\%) TB patients claim to have health insurance. This is in accordance with the statement on the Technical Instructions of TB patients services for BPJS participants "Health Insurance or BPJS will cover all medical expenses related to TB" (CDC, 2015). Moreover, according to the data claim BPJS, tuberculosis is one of the five most diseases in Indonesia (Setiaji, 2019).

The description of the quality of life of TB patients, it is known that at the baseline (early treatment) more TB patients are found with poor quality of life but subsequently, good quality of life has improved. These results is the same as research conducted by Hendrik, Perwitasari, Mulyani, and Thobari found that poor quality of life for TB patients occurred in the first month at the beginning of treatment (Hendrik, Perwitasari, Mulyani, \& At Thobari, 2015).

TB patients with supportive social support are 7.9 times more likely to have a better quality of life than TB patients with non-supportive social support with $95 \%$ CI: 5.6-11.2. The large OR results between social support and quality of life for TB patients show a strong association between social support and quality of life for TB patients. Temporal relationships in this study are shown in the design and course of the study. Data on exposure (supportive social support) is the result of measurement in the period of treatment (before the outcome occurs), while the quality of life of TB patients is the result of measurement at the next observation. Plausibility in terms of the biological mechanism of the influence of social support on the quality of life of TB patients can be explained that social support is related to the level of morbidity and mortality because it involves physiological mechanisms that will ultimately affect a person's quality of life. According to the principle of causality based on Hill's theory, the effect of social support on quality of life has a strong relationship, fulfilling the principle of temporality and plausibility (King, 2015).

This study showed that the provision of social support at the baseline, $2^{\text {nd }}$ month, $5^{\text {th }}$ month, and $6^{\text {th }}$ month influenced the quality of life of TB patients. The most effective time to provide social support to improve the quality of life of TB patients is in the initial stages of treatment (baseline until the 2nd month of treatment), where in the improvement in the quality of life of TB patients who receive supportive social support will continue to increase from 2 nd to $5^{\text {th }}$ months, $6^{\text {th }}$ month (end of treatment). The quality of life of TB patients towards the 6th month seems to increase sharply along with the course of their illness towards recovery. The critical time for TB patients is in the 2nd month of treatment as a qualitative study on pulmonary tuberculosis patients at BP4 Tegal conducted by Nugroho (Nugroho, 2011) concluded that the underlying factor for dropping out of TB patients is treatment after the $2^{\text {nd }}$ month of treatment where the symptoms disappear and the patient feels get well. This condition can encourage patients to stop treatment. Thus, the provision of social support at the end of the second $2^{\text {nd }}$ month of treatment becomes very important for the treatment of TB patients to achieve true healing.

This study shows that the source of social support that is influential to improve the quality of life of TB patients is support from family, friends and significant others. Social support from the family gives the strongest influence to improve the quality of life of TB patients Tety \& Turniani (Tety \& Turniani, 2006) stated that because treatment requires a long time, patients with pulmonary tuberculosis are very likely to experience high enough stress so that in addition to medical treatment is also needed social support from family and those around them. Putri, Wahiduddin, Arsyad in They study in Makassar on pulmonary tuberculosis patients stated that 56\% 
of pulmonary tuberculosis patients who received family support had a better quality of life than social support received from the community and friends (Putri et al., 2013).

In this study, the social support received by TB patients who influence to improve the quality of life of TB patients is emotional, informational, and companionship support. Emotional support provides the most powerful influence to improve the quality of life of TB patients. Research conducted by Melisa Prisilia Tarok, Jeavery Bawotong in of pulmonary tuberculosis patients at BLU Hospital Prof. DR R.D. Kandou Manado found that a high quality of life was in of pulmonary tuberculosis patients with high emotional support (67\%) (Melisa Prisilia Tarok, Jeavery Bawotong, 2012). Emotional support is the most powerful support in motivating recovery in TB patients (Tety \& Turniani, 2006).

The results of this study found a significant proportion of the impact, this proves that TB patients with non-supportive social support are a health problem that must be prevented and addressed. Supportive social support can improve the quality of life so that the elimination of non-supportive social support programs and interventions for the whole community to provide supportive social support to TB patients is the right program to improve the quality of life.

The limitations in this study were the time needed in a longitudinal study is too short to measure changes in the quality of life of TB patients (in just 6 months), the sample is small for a comparative studies that could compare quality of life of TB patients in supportive social support and non-supportive social support groups, data collection was conducted by interviewing patients, the researchers had not made direct observations on the environmental conditions (whether physical condition of the house is in accordance with health standards and healthy their residential environment), access to health services, and socioeconomic situations.

\section{Conclusion}

Social support to Tuberculosis patients given during the period of treatment have a positive impact on the quality of life. This study recommends improving the social support to Tuberculosis patients from family, friends and significant others in the emotional, informational and companionship support in order to make a better quality of life of Tuberculosis patients.

\section{Acknowledgments}

The Authors would like to thank to the Research and Community Development Center of Indonesia University for the financial support.

\section{Competing Interests Statement}

The authors declare that there are no competing or potential conflicts of interest.

\section{References}

Adnan, Perwitasari, D. A., \& Mulyani, U. (2014). Reliability and Validaty of St George Respiratory Questionnaire (SGRQ) into Indonesian Version. International Journal of Public Health Science (IJPHS), 3(3), 179-184. https://doi.org/10.11591/ijphs.v3i3.4691

Alexander, M., Berger, W., Buchholz, P., Walt, J., Burk, C., Lee, J., ... Abetz, L. (2005). The reliability, validity, and preliminary responsiveness of the Eye Allergy Patient Impact Questionnaire (EAPIQ). Health and Quality of Life Outcomes, 3, 1-11. https://doi.org/10.1186/1477-7525-3-67

CDC, M. (2015). Technical Instructions of Tuberculosis Patients Services for Health Insurance (BPJS) Participants.

Dhuria, M., Sharma, N., \& Ingle, G. (2008). Impact of Tuberculosis on the Quality of Life. Indian Journal of Community Medicine, 33(1), 58. https://doi.org/10.4103/0970-0218.39249

Hendrik, Perwitasari, D. A., Mulyani, U. A., \& At Thobari, J. (2015). Measuring Quality of Life of Tuberculosis Patients using St George Respiraory Questionnaire (SQRQ) Questionaire in Yogyakarta. 28-34.

King, J. (2015). Bradford Hill Criteria for Causal Inference. 29.

Kusmiyati, Y. (2016). Asphyxia Effect on the Quality Of Life of Children Aged 2-4 Years (Vol. 53). https://doi.org/10.1017/CBO9781107415324.004

Melisa Prisilia, T., \& Jeavery Bawotong, F. M. L. (2012). Relationship betwen Soscial Support and Quality of LIfe of Lung Tuberculosis Patients in Lung Unit RSUP Prof. Dr. R.D. Kandau Manado. Ejournal Keperawatan (E-Kp), 1(1), (August), 1-25.

MOH Indonesia. (2016). Tuberculosis Control Program. Jakarta: Kementerian Kesehatan RI. 
Nita Yunianti Ratnasari. (2012). Relationship between social support and quality of life in Tubercuosis patients di Balai Pengobatan Penyakit Paru (BP4) Yogyakarta Unit Minggiran. Jurnal Tuberkulosis Indonesia, 8, 1-6. Retrieved from https://www.academia.edu/10737968/JURNAL_TUBERKULOSIS_INDONESIA

Nugroho, R. A. (2011). Qualitatif Study Factors related to Drop Out Tuberkulosis Treatment in Balai Pegobatan Penyakit Paru- Paru Tegal (Vol. 7). https://doi.org/10.1007/s11094-009-0220-4

Pasipanodya, J. G., Miller, T. L., Vecino, M., Munguia, G., Bae, S., Drewyer, G., \& Weis, S. E. (2007). Using the St. George Respiratory Questionnaire to ascertain health quality in persons with treated pulmonary tuberculosis. Chest, 132(5), 1591-1598. https://doi.org/10.1378/chest.07-0755

Patel, P. G., Ramanuj, V., \& Bala, D. V. (2014). Assessment Quality of Life (QoL) of TB patients registered in tuberculosis units of Ahmedabad municipal corporation area by using WHO short form-36 (SF-36) questionnaire. Scholars Journal of Applied Medical Sciences, 2(August 2013), 3303-3306. Retrieved from http://saspublisher.com/wp-content/uploads/2014/11/SJAMS-26F3303-3306.pdf

Payot, A., \& Barrington, K. J. (2011). The Quality of Life of Young Children and Infants with Chronic Medical Problems: Review of the Literature. (April), 91-101. https://doi.org/10.1016/j.cppeds.2010.10.008

Putri, R. M., Wahiduddin, \& Arsyad, D. S. (2013). Relationship Social support with quality of life in Tuberculosis patients In BBKPM Makassar City. Repository.Unhas.Ac.Id.

Tety, R., \& Turniani, L. (2006). The influence of sosial support and knowledge of TB to the motivation of cure tuberculosis patients in Puskesmas. Buletin Penelitian Sistem Kesehatan, (1), 134-141. Retrieved 23 Desember, 2015, from ejournal.litbang.depkes.go.id/index.php/hsr/.../2741 diakses tanggal

Setiaji, B. R. (2019). 5 Most Disease Claimed to BPJS Indonesia. Retrieved from https://hellosehat.com/hidup-sehat/fakta-unik/penyakit-terbanyak-di-indonesia/

The WHOQOL Group. (2005). The World Helath Organization Quality of Life Assessment (WHOQOL): Position paper from The World Health Organization. Soc Sci Med, 41(10), 1403-1409. https://doi.org/10.1016/0277-9536(95)00112-K

Tinartayu, S., \& Riyanto, B. U. D. (2015). SF-36 as The Instrument for Measuring Quality of Life of Tuberculosis Patients. Mutiara Medika, 15(1), 7-14.

Twisk, J. W. R. (2013). Applied Longitudinal Data Analysis for Epidemiology: A Practical Guide. In Annals of Internal Medicine (Vol. 140). https://doi.org/10.7326/0003-4819-140-8-200404200-00042

WHO. (2010). Treatment of Tuberculosis Quidelines (4th ed.). Pneumologe, 16(2), 117-130. https://doi.org/10.1007/s10405-019-0234-x

Zimet, G. D., Dahlem, N. W., Zimet, S. G., \& Farley, G. K. (1988). The Multidimensional Scale of Perceived Social Support. Journal of Personality Assessment, 51(1), 30-41. https://doi.org/10.1207/s15327752jpa5201_2

\section{Appendix}

Table 1. Characteristics of New Patients with Bacteriologically Confirmed Pulmonary Tuberculosis $(\mathrm{n}=209)$

\begin{tabular}{lcc}
\hline Variable & n & Percentage (\%) \\
\hline Age (years) & & \\
$15-24$ & 34 & 16,3 \\
$25-34$ & 58 & 27,8 \\
$35-44$ & 40 & 19,1 \\
$45-54$ & 53 & 25,4 \\
$>55$ & 24 & 11,5 \\
\hline Gender & & \\
Male & 126 & 60,3 \\
Female & 83 & 39,7 \\
\hline
\end{tabular}




\begin{tabular}{lcc}
\hline Education Background & 46 & 22,0 \\
Elementary & 48 & 23,0 \\
Junior High & 100 & 47,8 \\
Senior High & 15 & 7,2 \\
Diploma/Bachelor & & 39,7 \\
\hline Occupation & 83 & 60,3 \\
Not Working & 126 & 32,1 \\
Working & & 67,9 \\
\hline Marital Status & 67 & 35,0 \\
Single/ Divorced/Widow & 142 & 64,1 \\
Married & & \\
\hline Medical Insurance & 75 & 99,2 \\
Not Have & 134 & 0,8 \\
Have & & \\
\hline HIV & 125 & 82,3 \\
No & 1 & 16,7 \\
Yes & & \\
\hline DM & 105 & 21 \\
No & & \\
Yes & 21 & \\
\hline
\end{tabular}

\section{Copyrights}

Copyright for this article is retained by the author(s), with first publication rights granted to the journal.

This is an open-access article distributed under the terms and conditions of the Creative Commons Attribution license (http://creativecommons.org/licenses/by/4.0/). 